\title{
Tabloidyzacja przekazu krakowskich mediów regionalnych na temat wyborów samorządowych - płaszczyzna treści
}

\section{$\mathrm{M}$} edia lokalne i regionalne pełnią w systemie demokratycznym funkcję szczególną. Ze względów oczywistych w swoim przekazie odnoszą się bowiem w znacznie szerszym zakresie niż media ogólnopolskie do lokalnych informacji i wydarzeń o charakterze politycznym, stając się w ten sposób głównym ośrodkiem mediatyzacji polityki lokalnej, a co za tym idzie i aktorem lokalnej komunikacji politycznej. Ich przekaz zyskuje spore znaczenie zwłaszcza przy okazji wyborów samorządowych, kiedy to dla wielu odbiorców stanowią one główne źródło informacji wyborczej. W tym kontekście ważną rolę pełni prasa codzienna, posiadająca istotną przewagę nad mediami elektronicznymi, których przekaz charakteryzuje się zwykle wyższym udziałem treści rozrywkowych ${ }^{1}$.

Oprócz funkcji informacyjnej media lokalne i regionalne pełnią naturalnie także cały szereg innych ról, w tym m.in. funkcję kontrolną, socjalizacyjno-wychowawcza, integracyjna, mobilizująca, a wreszcie i reklamowo-ogłoszeniową ${ }^{2}$. Jakość ich oddziaływania na postawy i zachowania polityczne ich odbiorców, a w tym konkretnym przypadku na ich zachowania wyborcze, zależy więc m.in. od tego, która funkcja przeważa w odniesieniu do przekazu na temat wyborów samorządowych oraz

1 R. Schulz, Nutzung von Zeitungen und Zeitschriften, w: Mediengeschichte der Bundesrepublik Deutschland, red. J. Wilke, Bundeszentrale für politische Bildung, Bonn 1999, s. 406-421. Por. także J. Adamowski, Społeczne funkcje mediów lokalnych, w: Media lokalne a demokracja lokalna, red. J. Chłopecki, R. Polak, Wydawnictwo Wyższej Szkoły Informatyki i Zarządzania, Rzeszów 2005, s. 44.

2 R. Kowalczyk, Prasa lokalna w systemie komunikowania społecznego, Instytut Nauk Politycznych i Dziennikarstwa UAM, Poznań 2003, cyt. za: J. Adamowski, op. cit., s. 36 . 
jakimi cechami się on charakteryzuje. Ostatni z wymienionych czynników ma przy tym bardzo istotny wpływ nie tylko na sposób, w jaki przekaz ten zaspokoi potrzeby informacyjne odbiorcy, ale i na wiarygodność samego medium ${ }^{3}$.

Rezultaty badań przekazu krakowskich gazet codziennych, których podstawowym celem była identyfikacja typów zachowań regionalnych dzienników opiniotwórczych w okresie kampanii samorządowych w latach $2006^{4}$ i 2010 oraz pełnionych przez nie funkcji w odniesieniu do wyborów na poziomie lokalnym, pokazały jednoznacznie, iż obecnie wyraźnie zmniejsza się znaczenie informacyjne tych mediów, a zarazem utrwala się i pogłębia proces akomodacji $i^{5}$ polityki, co wyraźnie wpływa również na zawartość przekazu mediów. Uzyskane wyniki badań pokazały również, że zakres funkcji społecznych realizowanych przez te media zmienia się bardzo dynamicznie. Przyjmowane przez nie zadania komunikacyjne ewoluują, w rezultacie czego zmniejsza się poziom informacyjności ich przekazu, a zwiększa jego perswazyjność ${ }^{6}$.

Uzyskane w 2006 r. wyniki analizy zawartości przekazu małopolskich dzienników regionalnych w odniesieniu do tematyki samorządowej kampanii wyborczej pozwoliły na ustalenie, że podobieństwo w przekazie badanych mediów ograniczało się w zasadzie do wymiaru ilościowego. Analiza jakościowa zawartości przekazu ujawniła natomiast wyraźnie bardzo różny stosunek objętych badaniem tytułów prasowych do kwestii wyborów samorządowych i tym samym brak jednego, dominującego modelu ich działania w odniesieniu do sytuacji wyborów. Badane tytuły

3 Por. J. Adamowski, op. cit., s. 41.

${ }^{4}$ Wyniki badań przeprowadzonych w roku 2006 przedstawione zostały w artykule autorstwa Agnieszki Hess i Agnieszki Szymańskiej pt. Medialny obraz wyborów samorzadowych na przykładzie krakowskich gazet lokalnych, w: Wybory samorzadowe w kontekście mediów i polityki, red. M. Magoska, Wydawnictwo Uniwersytetu Jagiellońskiego, Kraków 2008. Patrz także: A. Szymańska, Akomodacja $i$ atrakcyjność medialna polityki na przykładzie wyborów samorzqdowych $w$ świetle publikacji krakowskich dzienników, „Zeszyty Prasoznawcze” 2009, nr 3-4; A. Hess, Upartyjnienie wyborów samorzqdowych jako element lokalnej komunikacji politycznej. Partie polityczne w przekazie Gazety Krakowskiej w kampanii samorzqdowej w 2006 r., ,Zeszyty Prasoznawcze” 2010, nr 1-2.

5 Więcej na ten temat w: A. Szymańska, op. cit.

${ }^{6}$ M. Bukowski, A. Hess, J. Flis, A. Szymańska, Opcja czy osoba? Upartyjnienie versus personalizacja $w$ wyborach samorzadowych, Wydawnictwo Uniwersytetu Jagiellońskiego, Kraków 2011, s. 63-91. 
prezentowały zróżnicowane typy zachowań komunikacyjnych, realizowały w tym okresie zasadniczo odmienne funkcje społeczne (i czyniły to w odniesieniu do różnych poziomów komunikacji) względem swoich odbiorców, co pozwoliło na wyróżnienie wówczas trzech, jakościowo odrębnych typów podejścia mediów do sytuacji wyborów samorządowych, tj. typ medium-INFORMATORA, typ medium-ANIMATORA oraz typ medium-DOZORCY ${ }^{7}$.

Wyniki badań przeprowadzonych przy okazji kolejnych wyborów samorządowych i opierających się na tych samych kategoriach analizy pokazały, że te trzy jakościowo różne modele zachowań krakowskiej prasy codziennej w 2010 roku straciły na ostrości. Co prawda wyniki jakościowej analizy zawartości treści badanych dzienników nadal wskazywały na duże zróżnicowanie ich przekazu. Jednak jej rezultaty wskazały również istnienie kilku istotnych cech wspólnych dla wszystkich badanych tytułów, w tym m.in. wyraźny spadek liczby publikacji o charakterze czysto informacyjnym. To oznacza, że krakowskie dzienniki regionalne w 2010 r. w mniejszym niż uprzednio zakresie mogły stanowić dla swoich odbiorców źródło informacji na temat wyborów samorządowych. Także nierównomierne natężenie przekazu na temat poszczególnych poziomów samorządowej rywalizacji wyborczej nie był czynnikiem sprzyjającym kompletności oferty informacyjnej badanych mediów. Jednocześnie wzrosła liczba publikacji dotyczących kwestii kontrowersyjnych (konflikty, afery, skandale) oraz publikacji swobodnie animujących zainteresowanie czytelnika tematem wyborów ${ }^{8}$. W kontekście wspominanej na wstępie i dotychczas w obszarze komunikacji politycznej niejako zwyczajowo przyjmowanej wyższej przydatności prasy codziennej nad przekazem mediów elektronicznych, tendencje te świadczą o wyraźnie słabnącej roli tradycyjnych mediów drukowanych jako źródła informacji politycznej. Co więcej, zgodnie z definicją Howarda Kurtza" spadek wartości informacyjnej przekazu mediów i jednoczesny wzrost natężenia przekazów o charakterze sensacyjnym są klasycznymi przejawami tabloidyzacji informacji politycznej. W kontekście ostatnich wyborów

7 Patrz A. Hess, A. Szymańska, Medialny obraz wyborów samorzadowych..., op. cit.

${ }^{8}$ M. Bukowski, A. Hess, J. Flis, A. Szymańska, op. cit., s. 88-91.

9 Zob. D. Piontek, Komunikowanie polityczne i kultura popularna. Tabloidyzacja informacji o polityce, Wydawnictwo Naukowe WNPiD UAM, Poznań 2011, s. 187. 
samorządowych o nasilającej się obecności tego zjawiska w odniesieniu do przekazu regionalnej prasy codziennej świadczyć może także rosnąca (względem poprzedniej kampanii wyborczej) perswazyjność przekazu, która może być skutkiem osłabiania się funkcji edukacyjnej mediów i wzmacnianie się ich roli jako instrumentu marketingu politycznego, co w ujęciu Franka Essera ${ }^{10}$ jest wskaźnikiem zjawiska tabloidyzacji na poziomie makro systemu społecznego. W ten sposób analiza przekazu mediów, zmierzająca pierwotnie do ustalenia przyjmowanych przez poszczególne tytuły strategii informacyjnych, ujawniła cały szereg cech przekazu, świadczących o postępującym procesie tabloidyzacji przekazu regionalnych opiniotwórczych mediów drukowanych w odniesieniu do wyborów samorządowych, który to proces nie pozostaje obojętny dla jakości komunikacji politycznej na poziomie lokalnym.

W literaturze fachowej zjawisko tabloidyzacji zwykle opisywane jest w opozycji do tradycyjnego, jakościowego dziennikarstwa informacyjnego ${ }^{11}$. Tabloidyzacja wiązana jest zatem $\mathrm{z}$ odchodzeniem od takich jego cech, jak wiarygodność, wynikająca ze zrównoważenia, powagi i rzetelności podawanych informacji oraz wyrazistego oddzielania sfery publicznej i prywatnej ${ }^{12}$. Tabloidyzacja polega dalej na wzroście udziału treści i form rozrywkowych w przekazie informacyjnym mediów, większej stymulacji emocji, w tym wynikającej ze wzrostu natężenia częstotliwości i zakresu przekazów nacechowanych emocjonalnie, zmianie struktury podawanych informacji (struktura koła w miejsce piramidy informacyjnej) i formy ich narracji (odejście od formy analitycznej), wzroście udziału treści sensacyjnych, melodramatyzacji i postępującej estetyzacji przekazu. Zmianom tym towarzyszy tendencja do upraszczania i spłycania warstwy merytorycznej dyskursu ${ }^{13}$.

Zjawisko tabloidyzacji przekazu mediów drukowanych analizować należy zatem w odniesieniu do dwóch wymiarów jego przekazu: płaszczyzny treści i płaszczyzny formy. Niniejszy rozdział zaprezentuje wyniki badań, dotyczące tabloidyzacji przekazu mediów w odniesieniu do

10 Por. ibidem, s. 188.

11 Zob. D. Piontek, op. cit., s. 187-198, a także M. Lisowska-Magdziarz, Media powszechne. Środki komunikowania masowego i szerokie paradygmaty medialne w życiu codziennym Polaków u progu XXI wieku, Wydawnictwo Uniwersytetu Jagiellońskiego, Kraków 2008, s. 160-167.

12 Ibidem.

13 Ibidem. 
jego treści ${ }^{14}$. Stanowią one rezultat wtórnej analizy danych własnych, pochodzących z ilościowej i jakościowej analizy porównawczej przekazu małopolskich dzienników regionalnych „Gazety Krakowskiej” (od 2007 roku ukazującej się pod nazwą „Polska Gazeta Krakowska”), „Dziennika Polskiego” oraz krakowskiego dodatku „Gazety Wyborczej”, przeprowadzonej w celu ustalenia sposobu prezentacji małopolskich wyborów samorządowych, w tym poszczególnych ugrupowań politycznych oraz prezydenckiej kampanii wyborczej w Krakowie, a także typologii zachowań codziennej prasy regionalnej w zakresie komunikacji politycznej w sytuacji wyborów samorządowych w latach 2006 i 2010. Ramy czasowe i wielkość próby badawczej zostały zaprezentowane w tabeli 1.

Tabela 1

Ramy czasowe i wielkość próby badawczej

\begin{tabular}{||l|c|c|c||}
\hline & „Gazeta Krakowska” & „Dziennik Polski” & „Gazeta Wyborcza” \\
\hline $\mathbf{2 0 0 6}$ (1 września-12 listopada) & 251 & 204 \\
\hline Liczba publikacji & 256 & 65 (na 72) & 61 \\
\hline Liczba wydań & 61 & 159 & 107 \\
\hline $\mathbf{2 0 1 0}$ (27 października-20/21 listopada) & 20 & 20 \\
\hline Liczba publikacji & 146 & 20 & \\
\hline Liczba wydań & 20 &
\end{tabular}

Źródło: Opracowanie własne.

W celu odpowiedzi na pytanie dotyczące obecności charakterystycznych dla prasy tabloidowej cech przekazu w sposobie relacjonowania samorządowej kampanii wyborczej na łamach małopolskich dzienników regionalnych wykorzystano pięć wskaźników, odnoszących się z jednej strony do cech typowych dla dziennikarstwa tabloidowego, a z drugiej różnicujących dyskursy badanych tytułów prasowych (por. tabela 2). Wskaźniki wykorzystane do analizy zjawiska tabloidyzacji w odniesieniu do treści przekazu odnosiły się do analogicznych cech dziennikarstwa tabloidowego, którymi posłużono się w przeprowadzonej symetrycznie analizie zjawiska tabloidyzacji na płaszczyźnie formy.

14 Wyniki analizy uzyskane w odniesieniu do płaszczyzny formy zawiera rozdział autorstwa A. Hess, Małopolskie dzienniki regionalne w procesie tabloidyzacji przekazu na temat wyborów samorzadowych - płaszczyzna formy. 
Tabela 2

Wskaźniki zróżnicowania dyskursu mediów w odniesieniu do treści ich przekazu

\begin{tabular}{||l|l||}
\hline \multicolumn{1}{|c|}{ Wskaźnik } & \multicolumn{1}{|c|}{ Plaszczyzna treści } \\
\hline $\begin{array}{l}\text { Urozrywkowienie } \\
\text { (infotainment) }\end{array}$ & $\begin{array}{l}\text { Wzrost udziału treści rozrywkowych (podporządkowanie rozrywce) } \\
\text { lub/i poziomu emocjonalności (w celu emocjonalnego pobudzenia) } \\
\text { przekazu. }\end{array}$ \\
\hline Retoryka sporu & $\begin{array}{l}\text { Wzrost udziału przekazów dotyczących tematów kontrowersyjnych, } \\
\text { treści sensacyjnych. }\end{array}$ \\
\hline Personalizacja & $\begin{array}{l}\text { Dominacja zainteresowania wyborami do tych instytucji, w których } \\
\text { czytelny jest KONKRETNY kandydat; marginalizacja przekazu na te- } \\
\text { mat pozostałych instytucji. }\end{array}$ \\
\hline Nacechowanie & $\begin{array}{l}\text { Wzrost przekazów zawierających elementy/wyrażenia nacechowane } \\
\text { emocjonalnie. }\end{array}$ \\
\hline Uproszczenie & $\begin{array}{l}\text { Zakres przekazu nie odnosi się do całości tematyki: tylko niektóre ob- } \\
\text { szary są tematyzowane. }\end{array}$ \\
\hline
\end{tabular}

Źródło: Opracowanie własne.

Pierwszą z cech dziennikarstwa typowego dla tabloidów, która w przeprowadzonych badaniach przekazu krakowskich mediów regionalnych posłużyła za wskaźnik tabloidyzacji stało się urozrywkowienie przekazu (ang. infotainment), oznaczające wzrost udziału treści rozrywkowych lub/i poziomu emocjonalności przekazu. Ponieważ, jak wspomniano powyżej, analiza miała charakter wtórnej analizy danych, identyfikację poziomu urozrywkowienia przekazu ograniczono do ilościowego udziału publikacji o charakterze czysto informacyjnym na temat samorządowej kampanii wyborczej oraz ilościowego udziału publikacji dotyczących działań aktywizujących odbiorców przekazu do zainteresowania lub/i udziału w wyborach samorządowych.

Jak widać na wykresie 1, prezentującym odsetek publikacji o charakterze czysto informacyjnym, czyli zawierających wyłącznie pozbawione komentarzy odautorskich informacje odnośnie wyborów samorządowych, ich natężenie w całości przekazu na temat wyborów samorządowych wyraźnie spada. Jedyne odstępstwo w tym zakresie stanowi przekaz „Gazety Wyborczej”, gdzie odsetek takich informacji w roku 2010 wzrósł w stosunku do danych uzyskanych cztery lata wcześniej. Jednak, co widać na wykresie 6, nawet w przypadku tego tytułu prasowego liczba publikacji o charakterze informacyjnym jest znacznie niższa od liczby publikacji zawierających jednoznaczną pozytywną lub/i negatywną ocenę relacjonowanych wydarzeń. 
Wykres 1. Odsetek publikacji o charakterze czysto informacyjnym w przekazie na temat wyborów samorządowych

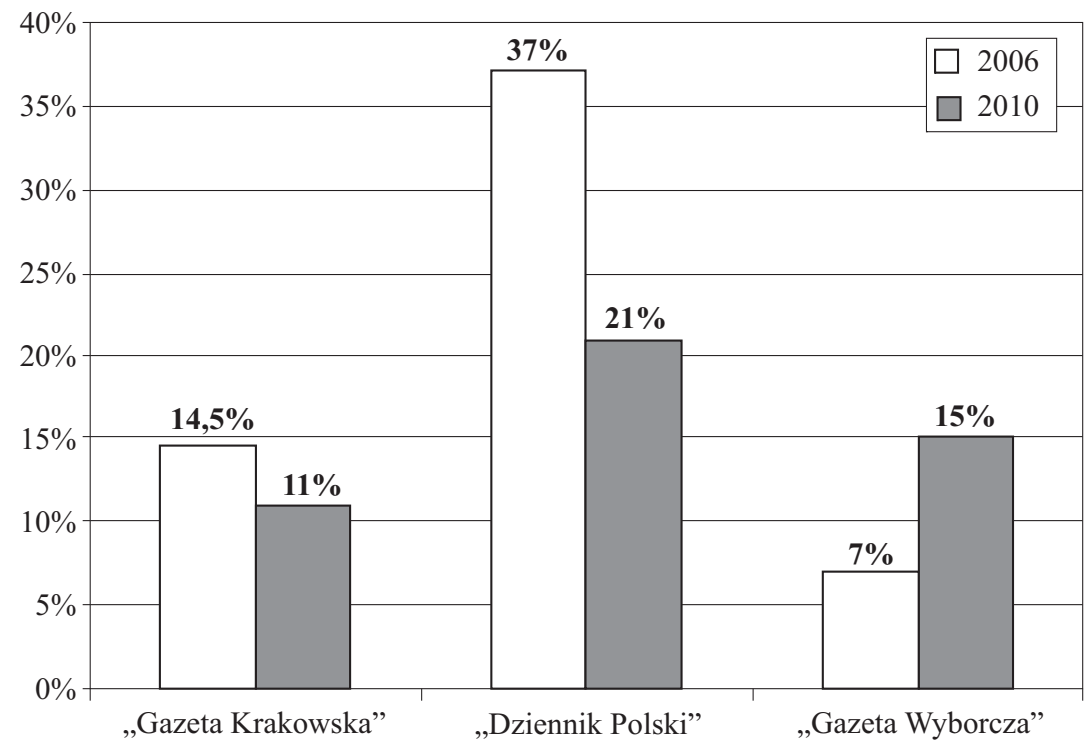

Źródło: Opracowanie własne.

W przekazie badanych gazet wzrastał jednocześnie odsetek publikacji, dotyczących podejmowanych przez poszczególne redakcje inicjatyw aktywizujących odbiorców przekazu do zainteresowania lub/i udziału w wyborach samorządowych. W roku 2010 najwięcej tego typu publikacji zostało zamieszczonych na łamach „Gazety Wyborczej” (22\%). W przekazie pozostałych dwu dzienników odniesienie/zapowiedź tego rodzaju działań zawierało $12 \%$ wszystkich objętych badaniem jednostek wypowiedzi prasowej. Za wyjątkiem przekazu „Dziennika Polskiego" w przypadku obu pozostałych tytułów także tej kategorii publikacji było więcej niż publikacji o charakterze czysto informacyjnym.

Za drugi wskaźnik tabloidyzacji przyjęto w badaniu obecność tzw. retoryki sporu. Jej przejawem miał stać się wzrost liczby przekazów dotyczących tematów kontrowersyjnych i treści sensacyjnych. Jak wynika z uzyskanych danych, prezentowanych graficznie na wykresie 2, w badanym okresie taki wzrost nastapił w przypadku wszystkich trzech badanych tytułów, choć z różnym natężeniem. Największy wzrost w tym zakresie w 2010 r. zanotowano w odniesieniu do przekazu „Dziennika Polskiego", którego przekaz jeszcze w roku 2006 cechował wśród 
badanych tytułów najmniejszy udział tego typu treści. Cztery lata później „Dziennik Polski” dorównał w tym względzie „Gazecie Wyborczej”, charakteryzującej się najwyższym udziałem tego typu publikacji w całości przekazu już w przypadku poprzednich wyborów samorządowych, co generalnie wpłynęło na znaczne ujednolicenie dyskursu.

Wykres 2. Odsetek publikacji zawierających odniesienie do kontrowersji i konfliktów

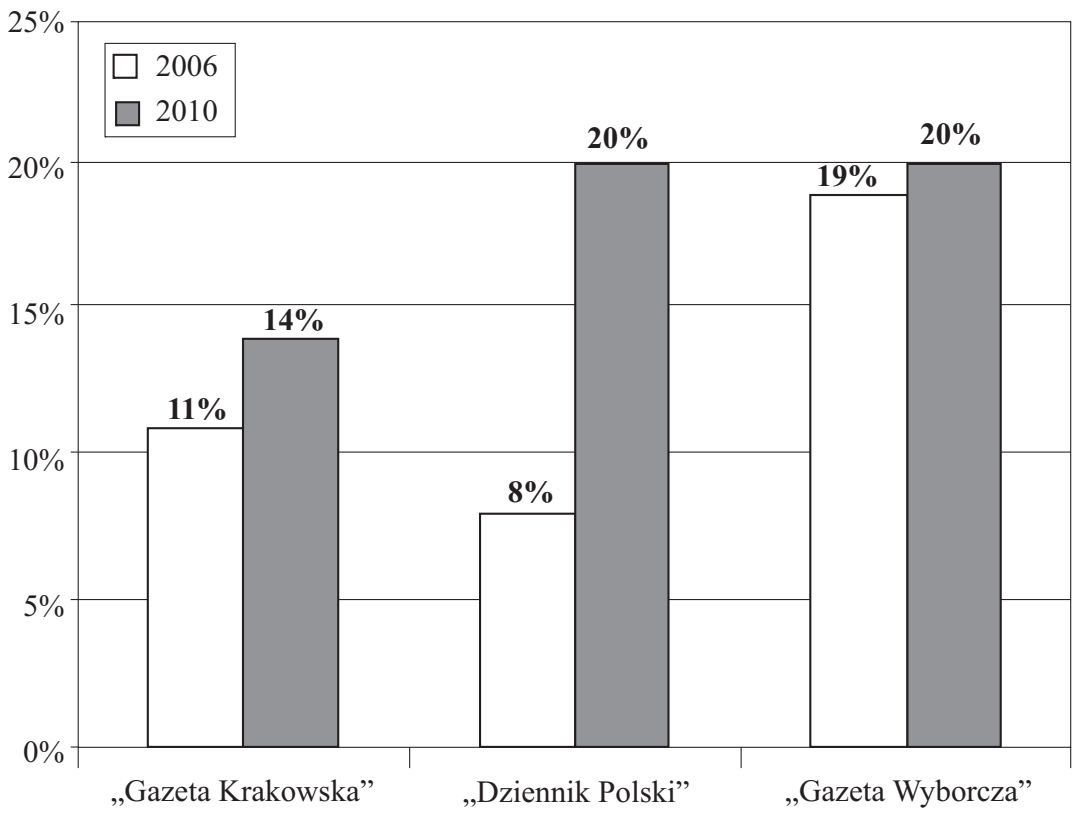

Źródło: Opracowanie własne.

Potwierdzeniem tego stanu rzeczy stały się także wyniki badań, odnoszące się do rozkładu tematyki przekazu dotyczącego kwestii kontrowersyjnych, z których wynika, że przekaz wszystkich trzech objętych badaniem tytułów prasowych był w tym zakresie bardzo jednorodny. Jak wynika $\mathrm{z}$ danych, zamieszczonych w tabeli 3, zróżnicowanie tematyczne przekazu poszczególnych gazet było, w odniesieniu do treści dotyczących kontrowersji i konfliktów, bardzo niewielkie. Zatem w bardzo niewielkim stopniu ich przekaz mógł uzupełniać się nawzajem. 
Tabela 3

Tematyka publikacji zawierających odniesienie do kontrowersji i konfliktów

\begin{tabular}{||l|c|c|c||}
\hline \multicolumn{1}{|c|}{ Tematyka publikacji } & $\begin{array}{c}\text { "Gazeta } \\
\text { Krakowska" }\end{array}$ & $\begin{array}{c}\text { "Dziennik } \\
\text { Polski” }\end{array}$ & $\begin{array}{c}\text { "Gazeta } \\
\text { Wyborcza" }\end{array}$ \\
\hline $\begin{array}{l}\text { Kontrowersje wokół konstrukcji list (wybór kan- } \\
\text { dydatów i styl rejestracji) }\end{array}$ & + & + & + \\
\hline $\begin{array}{l}\text { Skutki wykluczeń z partii dla klimatu kampanii sa- } \\
\text { morządowej }\end{array}$ & & + & + \\
\hline $\begin{array}{l}\text { Plakatowanie miejsc bez wymaganego pozwole- } \\
\text { nia/zaklejanie (wzajemne) plakatów wyborczych } \\
\text { przez konkurentów }\end{array}$ & + & + & + \\
\hline $\begin{array}{l}\text { Nietrafione/niedokończone inwestycje Jacka Maj- } \\
\text { chrowskiego }\end{array}$ & + & + & + \\
\hline $\begin{array}{l}\text { Dawne afery ('mostowa' prezydenta A. Gołasia; } \\
\text { 'hotelowa' J. Majchrowskiego; 'niegospodarność' } \\
\text { St. Kracika i in.) }\end{array}$ & + & + & + \\
\hline $\begin{array}{l}\text { Kontrowersje wokół finansowania kampanii (nie- } \\
\text { etyczny lobbing; promocja własnej firmy; kampa- } \\
\text { nia w godzinach pracy/za pieniądze publiczne) }\end{array}$ & + & + & + \\
\hline Łamanie procedur wyborczych (różne przypadki) & + & + & + \\
\hline
\end{tabular}

Źródlo: Opracowanie wlasne.

Trzecim, wykorzystanym w badaniach wskaźnikiem tabloidyzacji była personalizacja przekazu, za przejaw której przyjęto dominację zainteresowania wyborami do tych instytucji, w których czytelny jest konkretny kandydat, a której konsekwencją jest marginalizacja przekazu na temat wyborów do pozostałych instytucji samorządowych. Wykresy 3 i 4 prezentują dane, dotyczące natężenia przekazu w odniesieniu do poszczególnych płaszczyzn rywalizacji wyborczej w latach 2006 i 2010. Symbol PREZ KRK oznacza publikacje dotyczące wyborów na stanowisko prezydenta Krakowa, PREZ - prezydenta innych miast małopolskich, B - burmistrza, W - wójta, SW - Sejmiku Wojewódzkiego, RM - Rady Miasta, RP - Rady Powiatu, RG - Rady Gminy, RD - Rady Dzielnicy.

Uzyskane wyniki pokazują, że w 2010 r. największym zainteresowaniem krakowskiej prasy codziennej cieszyły się zdecydowanie wybory na stanowisko prezydenta miasta Krakowa, a następnie do Rady Miasta, nieco mniejszym do Sejmiku Województwa Małopolskiego. Zdecydowanie mniejszym zainteresowaniem cieszyły się natomiast wybory na prezydentów innych miast, burmistrzów, wójtów oraz do rad powiatów, 
Wykres 3. Odsetek publikacji na temat wyborów do poszczególnych szczebli wladzy samorządowej w 2006 roku

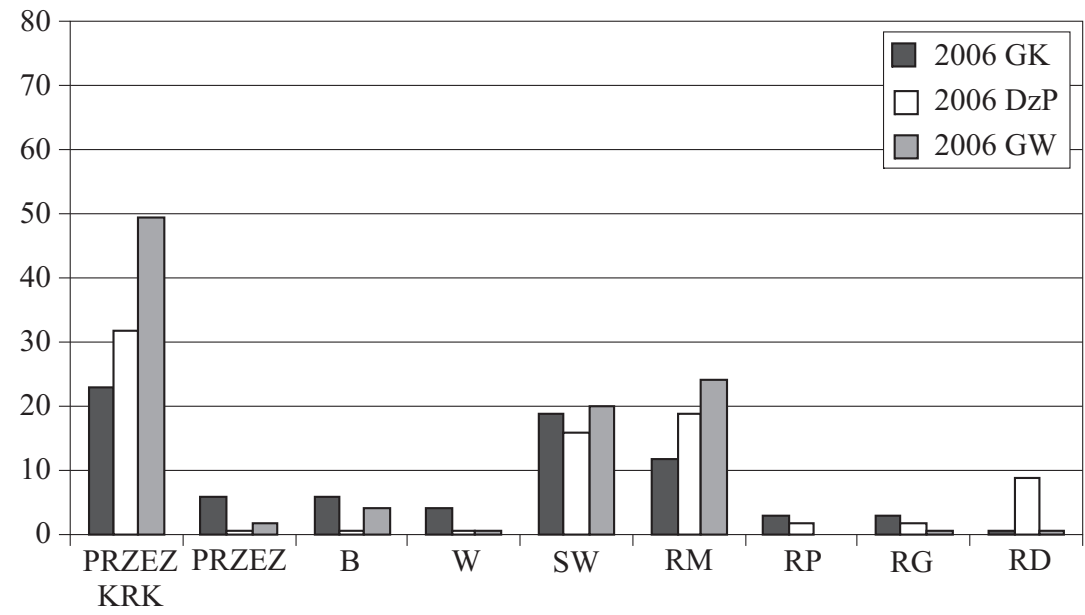

Źródło: Opracowanie własne.

gmin i dzielnicy. Stosunkowo największym zainteresowaniem wyborami do tych instytucji zainteresowany był zespół redakcyjny „Gazety Krakowskiej”, natomiast najwyraźniej tę dysproporcję zainteresowania

Wykres 4. Odsetek publikacji na temat wyborów do poszczególnych szczebli władzy samorządowej w 2010 roku

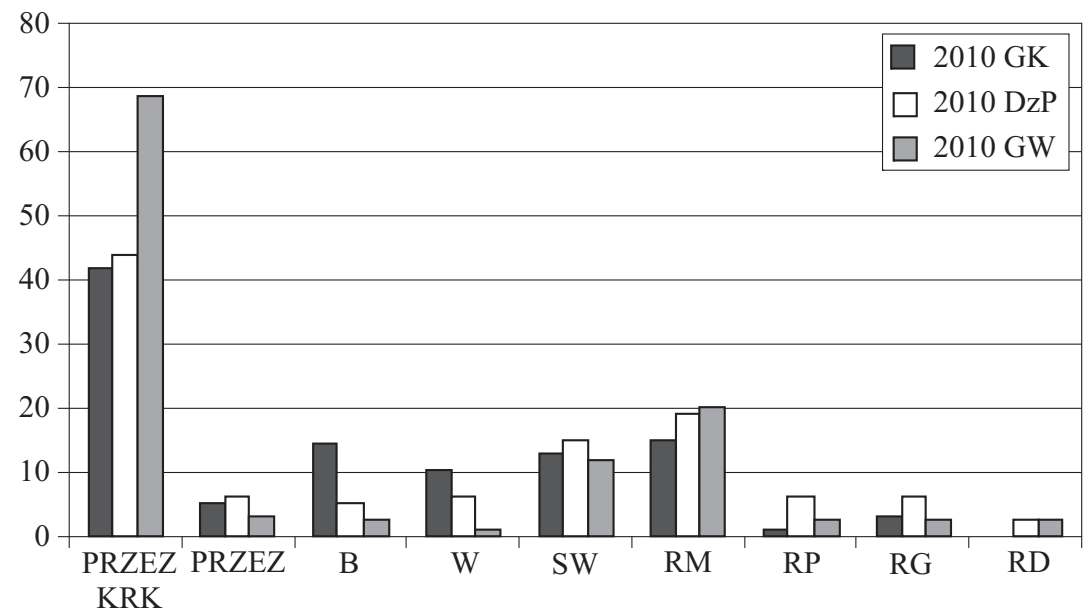

Źródło: Opracowanie własne. 
widać na łamach krakowskiego dodatku „Gazety Wyborczej”. Reasumując, o niezwykle mocnej personalizacji przekazu dotyczącego wyborów samorządowych w 2010 r. świadczy, iż w sumie ponad 40\% przekazów „Gazety Krakowskiej” i „Dziennika Polskiego” oraz blisko 70\% przekazów „Gazety Wyborczej”, zawierało odniesienie do wyborów na stanowisko prezydenta miasta Krakowa, które to wybory dokonywane są w sytuacji najlepszej rozpoznawalności osób w nich kandydujących.

Jednocześnie, jeśli porównać wyniki badań z lat 2006 i 2010, to widać wyraźnie, że zainteresowanie krakowskich dzienników tą płaszczyzną rywalizacji politycznej w kontekście wyborów samorządowych znacznie się pogłębia i to w odniesieniu do wszystkich trzech tytułów prasowych objętych badaniem. Na przykład na łamach „Gazety Krakowskiej” prezydencka kampania wyborcza w Krakowie w przypadku ostatnich wyborów stała się blisko dwa razy częściej niż w 2006 r. tematem publikacji. W przekazie „Dziennika Polskiego” jej frekwencja wzrosła o 12\%, a w „Gazecie Wyborczej” o 20\% (i uzyskała poziom 69\%!), i to pomimo tego, że już w 2006 r. blisko połowa publikacji zamieszczonych na łamach jej krakowskiego dodatku dotyczyła właśnie tej płaszczyzny rywalizacji politycznej w wyborach samorządowych. Z przyczyn oczywistych powoduje to istotne ograniczenie objętości przekazu na temat wyborów do innych organów władzy samorządu terytorialnego i generuje istotne $\mathrm{z}$ punktu widzenia jakości oferty informacyjnej badanych mediów luki informacyjne. Dane te świadczą również o znacznym uproszczeniu medialnego wizerunku wyborów samorządowych, zaprezentowanego na łamach badanych tytułów. Uproszczenie przekazu przyjęto za piąty, ostatni wskaźnik tabloidyzacji (por. tabela 2), przejawiający się nierównomiernym rozkładem przekazu w obrębie całości tematyki, w efekcie którego niektóre obszary są pomijane, inne zaś nadreprezentowane w treści przekazu. Stąd wyniki w tym zakresie można interpretować łącznie z rezultatami dotyczącymi wskaźnika personalizacja.

Jako czwarty wskaźnik tabloidyzacji, uzupełniający analizę dokonaną w odniesieniu do wskaźnika pierwszego, wykorzystano natomiast nacechowanie emocjonalne przekazu, którego miernikiem stała się liczba przekazów zawierających jednoznaczną pozytywną lub/i negatywną ocenę relacjonowanych wydarzeń. Wyniki analizy w tym zakresie są mniej jednoznaczne.

Uzyskane wyniki badań pokazują bowiem (por. wykres 5), że wyborczy przekaz krakowskich dzienników w roku 2010 jest różny pod względem częstotliwości publikacji zawierających jednoznaczną ocenę 
relacjonowanych kwestii od przekazu z roku 2006. Jednak, wbrew oczekiwanej tendencji wzrostu, w 2010 r. we wszystkich trzech objętych badaniem tytułach prasowych nastapił spadek - w stosunku do wyników z roku 2006 - częstotliwości publikacji zawierających jednoznaczną ocenę. Relatywnie największa zmiana dotyczyła „Dziennika Polskiego”, gdzie o blisko połowę spadł udział procentowy tego rodzaju publikacji. W przypadku „Gazety Wyborczej” ten spadek jest co prawda nominalnie wyższy (wynosi 12\%), jednak nadal dotyczy bardzo wysokiego odsetka publikacji (38\% w 2010 r. i 50\% w 2006 r. wszystkich zaklasyfikowanych do badań jednostek wypowiedzi prasowej). Niewielki, tzn. tylko dwuprocentowy spadek, odnotowano natomiast w tym zakresie w odniesieniu do przekazu „Gazety Krakowskiej”.

Wykres 5. Odsetek publikacji zawierających jednoznaczną ocenę w przekazie dotyczącym wyborów samorządowych

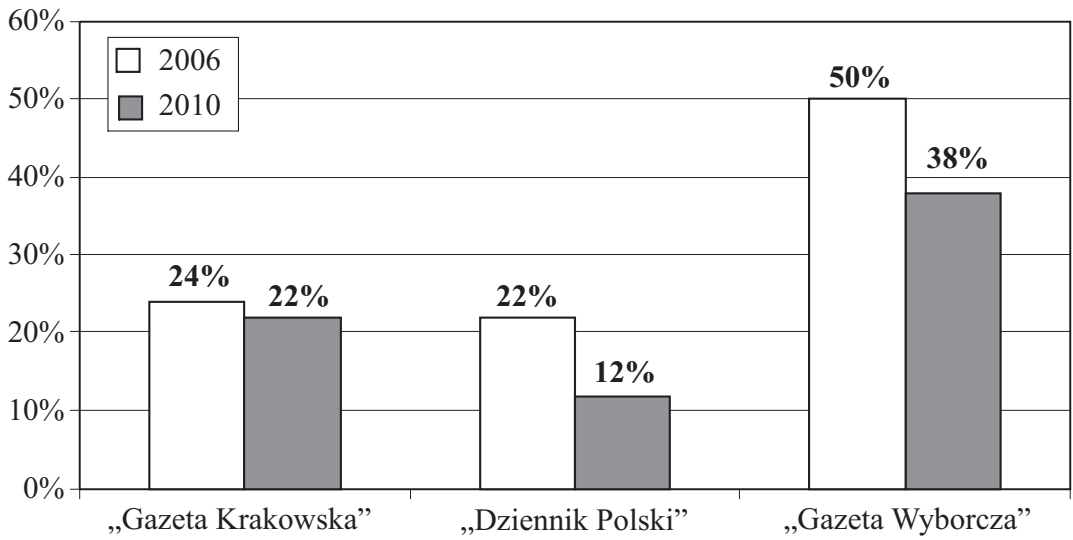

Źródło: Opracowanie własne.

Co ciekawe, wyniki analizy dotyczącej częstotliwości publikacji prezentujących jednoznaczną pozytywną lub/i negatywną ocenę redakcji $\mathrm{w}$ odniesieniu do relacjonowanych wydarzeń, pokazały w przypadku „Gazety Wyborczej”, tj. tytułu zawierającego najwyższy odsetek tego typu publikacji, dość zaskakującą relację opinii pozytywnie i negatywnie nacechowanych. W sumie niemal cztery z każdych dziesięciu tekstów, zamieszczonych w kontekście wyborów samorządowych w krakowskim dodatku GW, zawierało jednoznaczną pozytywną lub/i negatywną ocenę relacjonowanych wydarzeń. W przypadku „Gazety Krakowskiej” taką 
ocenę zawierała mniej więcej co piąta publikacja, a na łamach „Dziennika Polskiego” co ósma. Wbrew ogólnej tendencji przekaz „Gazety Wyborczej” częściej zawierał jednak ocenę pozytywną, niż negatywną (sic!). W odniesieniu do pozostałych dwóch tytułów prasowych, objętych badaniem, ta relacja była odwrotna. Szczegółowe dane zawiera tabela 4.

Tabela 4

Natężenie publikacji prezentujących w 2010 r. jednoznaczną ocenę ${ }^{15}$

\begin{tabular}{||l|c|c|c|c|c|c|c||}
\hline \multicolumn{1}{|c|}{ Tytul prasowy } & \multicolumn{2}{c|}{$\begin{array}{c}\text { „Gazeta } \\
\text { Krakowska" }\end{array}$} & \multicolumn{2}{c|}{$\begin{array}{c}\text { "Dziennik } \\
\text { Polski” }\end{array}$} & \multicolumn{2}{c||}{$\begin{array}{c}\text {,Gazeta } \\
\text { Wyborcza" }\end{array}$} \\
\hline Liczba publikacji ogółem & $\%$ & 32 & $22 \%$ & 19 & $12 \%$ & 41 & $38 \%$ \\
\hline $\begin{array}{l}\text { Liczba publikacji nacechowanych } \\
\text { OGÓŁEM }\end{array}$ & $\%$ & 11 & $8 \%$ & 2 & $1 \%$ & 37 & $35 \%$ \\
\hline $\begin{array}{l}\text { Liczba publikacji nacechowanych } \\
\text { POZYTYWNIE }\end{array}$ & $\%$ & 21 & $14 \%$ & 17 & $11 \%$ & 14 & $13 \%$ \\
\hline $\begin{array}{l}\text { Liczba publikacji nacechowanych } \\
\text { NEGATYWNIE }\end{array}$ & $\%$ & & \multicolumn{2}{|c|}{146} & \multicolumn{2}{c||}{159} & \multicolumn{2}{c||}{107} \\
\hline
\end{tabular}

Źródło: Opracowanie własne.

W kontekście nacechowania trudno byłoby zatem przyjmować interpretację, zgodnie z którą uzyskane wyniki mogą świadczyć o tabloidyzacji przekazu badanych mediów. Interpretacja tych danych może jednak stać się mniej jednoznaczna, jeśli wziąć pod uwagę relację pomiędzy częstotliwością publikacji nacechowanych i informacyjnych (por. wykres 6).

$\mathrm{Z}$ zestawienia tych danych wynika bowiem, że w przypadku ostatnich wyborów samorządowych w porównaniu do roku 2006 co prawda rzeczywiście spadła liczba publikacji zawierających jednoznaczną ocenę, jednak w odniesieniu do dwóch spośród trzech badanych tytułów nadal była ona wyższa niż publikacji o charakterze czysto informacyjnym. W sumie oznacza to, że dyskurs badanych mediów, z wyjątkiem przekazu „Dziennika Polskiego”, jest w wyższym stopniu nacechowany emocjonalnie aniżeli informacyjnie, a także, jak powiedziano wyżej, bardziej perswazyjny niż informacyjny.

15 Niektóre wypowiedzi prasowe zawierały zarówno ocenę pozytywną, jak i negatywną (wypowiedzi ambiwalentne), stąd ogólna liczba nacechowanych jednostek wypowiedzi prasowej nie zawsze równa jest sumie tekstów nacechowanych negatywnie i pozytywnie. 
Reasumując, uzyskane wyniki badań każą raczej przyjąć, iż tabloidyzacja przekazu krakowskich gazet lokalnych stała się faktem dokonanym. Świadczą o tym zarówno wzrastające urozrywkowienie przekazu tych mediów, jak i wyraźnie rosnąca tendencja do skandalizacji gry wyborczej na ich łamach. Dowodzi tego również pogłębiająca się personalizacja ich przekazu politycznego, a także fragmentaryzacja i uproszczenie dyskursu wyborczego oraz, co jest szczególnie istotne zwłaszcza w kontekście bardzo słabej przyswajalności informacji politycznej z serwisu mediów elektronicznych ${ }^{16}$, wyraźny spadek ich waloru informacyjnego. Wszystkie te elementy dowodzą, że proces tabloidyzacji, najsilniej cechujący jak dotąd przekaz mediów elektronicznych, wyraźnie staje się odczuwalny również $\mathrm{w}$ odniesieniu do serwisu informacyjnego dzienników regionalnych, czego przykładem stał się przekaz trzech krakowskich

Wykres 6. Natężenie publikacji nacechowanych i informacyjnych w 2006 r. i 2010 r. $^{17}$

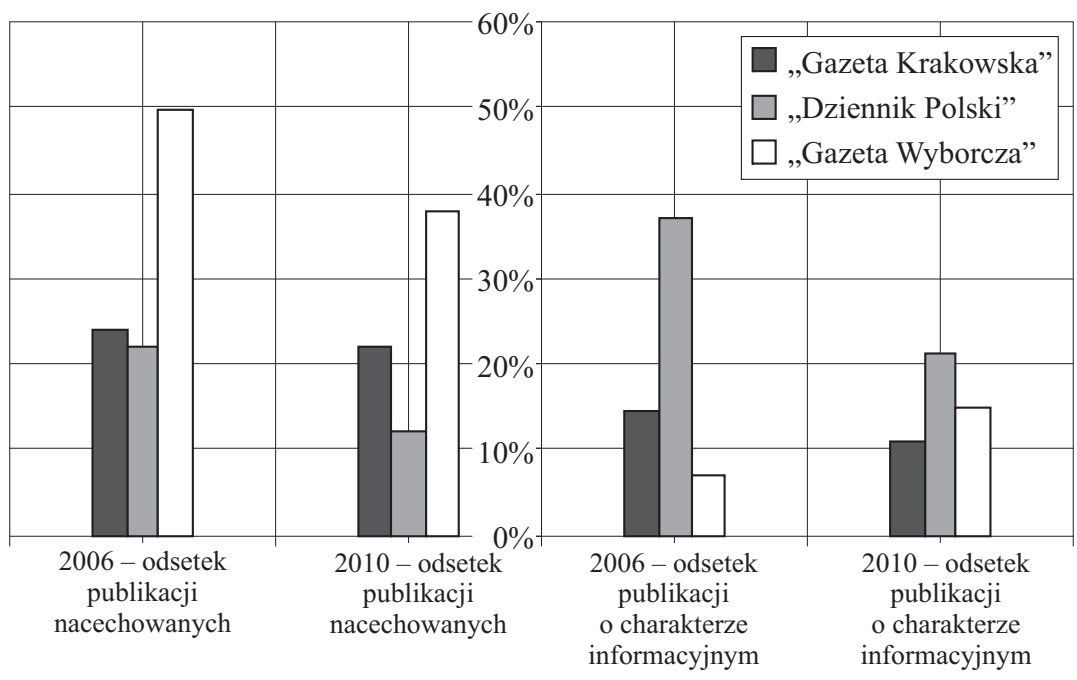

Źródlo: Opracowanie własne.

${ }^{16}$ M. Lisowska-Magdziarz, op. cit., s. 168. Autorka przywołuje wyniki badań lubelskiego badacza Piotra Francuza.

${ }_{17}$ Odsetek publikacji uzyskanych w odniesieniu do roku 2006 dotyczył dłuższego okresu badawczego i w związku z tym pełni jedynie funkcję orientacyjną. Liczba publikacji n za rok 2010 jw. W roku 2006 dla „Gazety Krakowskiej” n = 256, dla „Dziennika Polskiego” n = 251, dla „Gazety Wyborczej” $n=204$. 
dzienników na temat wyborów samorządowych. Dzisiaj jest jeszcze za wcześnie, aby móc wyrokować o tym, jaki wpływ tabloidyzacja przekazu medialnego będzie mieć na jakość gry demokratycznej. Jednak już dziś przypuszczać należy, iż nie będzie to niestety zjawisko dla jakości systemu demokratycznego obojętne, nie tylko na płaszczyźnie lokalnej.

\section{Bibliografia}

Adamowski J., Społeczne funkcje mediów lokalnych, w: Media lokalne a demokracja lokalna, red. J. Chłopecki, R. Polak, Wydawnictwo Wyższej Szkoły Informatyki i Zarządzania, Rzeszów 2005.

Bukowski M., Hess A., Flis J., Szymańska A., Opcja czy osoba? Upartyjnienie versus personalizacja w wyborach samorzadowych, Wydawnictwo Uniwersytetu Jagiellońskiego, Kraków 2011.

Hess A., Szymańska A., Medialny obraz wyborów samorzqdowych na przykładzie krakowskich gazet lokalnych, w: Wybory samorzqdowe w kontekście mediów i polity$k i$, red. M. Magoska, Wydawnictwo Uniwersytetu Jagiellońskiego, Kraków 2008.

Hess A., Upartyjnienie wyborów samorzqdowych jako element lokalnej komunikacji politycznej. Partie polityczne w przekazie Gazety Krakowskiej w kampanii samorzqdowej w 2006 r., „Zeszyty Prasoznawcze” 2010, nr 1-2.

Lisowska-Magdziarz M., Media powszechne. Środki komunikowania masowego i szerokie paradygmaty medialne w życiu codziennym Polaków u progu XXI wieku, Wydawnictwo Uniwersytetu Jagiellońskiego, Kraków 2008.

Piontek D., Komunikowanie polityczne i kultura popularna. Tabloidyzacja informacji o polityce, Wydawnictwo Naukowe WNPiD UAM, Poznań 2011.

Schulz R., Nutzung von Zeitungen und Zeitschriften, w: Mediengeschichte der Bundesrepublik Deutschland, red. J. Wilke, Bundeszentrale für politische Bildung, Bonn 1999.

Szymańska A., Akomodacja i atrakcyjność medialna polityki na przykładzie wyborów samorzadowych $w$ świetle publikacji krakowskich dzienników, „Zeszyty Prasoznawcze" 2009, nr 3-4.

The tabloidization of the coverage of local government elections by the regional media in Kraków - aspects of content

\section{Summary}

The paper deals with the issue of the social roles and functions of local and regional media in the modern democratic system as regards the mediatization of local 
politics during local government elections. It presents the results of surveys on the content of daily newspapers in Kraków conducted by Agnieszka Hess and Agnieszka Szymańska during the elections in 2006 and in 2010. This paper presents the results of an analysis of the tabloidization of the coverage of local government elections by the Kraków press in relation to its content. The results of the studies of media coverage in 2006 and in 2010 indicate a changing range of communication tasks and roles assumed by various newspapers and the intensification of the tabloidization process of media coverage as regards the manner and content of reports on the local elections. 